\title{
Promotion of Entrepreneurship in West-Africa, Lessons from China
}

\author{
Rodrigue Againglo, Junshan Gao \\ University of Science and Technology Beijing (USTB), Beijing, China \\ Email: 1196928602@qq.com
}

Received 29 June 2016; accepted 25 July 2016; published 28 July 2016

Copyright (C) 2016 by author and Scientific Research Publishing Inc.

This work is licensed under the Creative Commons Attribution International License (CC BY).

http://creativecommons.org/licenses/by/4.0/

(c) (i) Open Access

\begin{abstract}
African population is increasing rapidly as expected. It impacts negatively on their economic development. To solve that, we refer to the entrepreneurship, a basic way to improve significantly and help African countries in general. Apart from its contribution to the literature review for future researchers, the objective of this study is promotional and motivational of self-employments. Chinese approach (that is a part of good and useful experiences for implementation in African societies) and African demands (in entrepreneurship) are the headlines on the present topic. This current research was made in Benin, and found out eight (8) types of entrepreneurial activities. Significantly, there is $38.9 \%$ interest on trading whereas $21.18 \%$ on services, both of which are attractive to the Beninese. The entrepreneurs' education backgrounds have shown three levelsvocational practitioners with non-degree $(\mathbf{7 0 \%})$, the professionals and seniors executive (superior responsible) with universities degrees $(30 \%)$. The younger $(5.93 \%)$ entrepreneurs are under 25 years old. They are increasing after reaching 30 years old and get balance at 40 , and later, decrease progressively. It is recommended to African governments to promote their scholars through more financial aids to the mass public in order to improve and contribute to the development of the continent.
\end{abstract}

\section{Keywords}

Entrepreneurship's Promotion, Unemployment in Africa, Skills Development, Economics Growth, China's Entrepreneurs

\section{Objective of This Research}

Apart from its contribution to the literature review, the main purpose of this study is to promote and motivate the youth for going through an entrepreneurial mindset, to innovate and create more jobs for the mass degree and non-degree holders in Africa. 
This study is important for African societies and many organizations. The youth's skill development and management in entrepreneurship — both new and existing enterprises, contribute to the economic growth and social development. We believe that it should be understood and promoted as a vital part of education in the business because it provides the growth of job employments, happiness and emancipation of mind closing, multiple disciplines and activities for the youth to reach their expectations.

\section{Literature Review}

\subsection{Entrepreneurship Generalization}

It is the capacity and willingness to develop, organize and manage a business venture along with any of its risks in order to make a profit. The most obvious example of entrepreneurship is the starting of new businesses.

An entrepreneur is someone that organizes, manages, and assumes the risks of a business. He is an agent of change. Entrepreneurship is the process of discovering new ways of combining resources. When the market value provided by this new combination of resources is greater than the market value, these resources can generate individually somewhere, then, the entrepreneur makes a profit.

According to a business dictionary, innovation is the process of translating an idea or invention into a good or service that creates value or which customers will pay.

A distinction is made between invention, idea made manifest, and innovation, ideas applied successfully [1]. Drucker viewed innovation as an instrument used (by entrepreneurs) to exploit new changing as an opportunity [2]. The field of international is evaluation and exploitation of those opportunities in order to create future goods and services [3].

Entrepreneur is someone that is willing to engage in a risk acceptance provided by self-employment. The engagement can vary from survival to growth-oriented activities.

Since 1997, scholars at Babson College and London Business School, Global Entrepreneurship Monitor (GEM) developed one of the world's leading research consortia focused on more understanding about entrepreneurship and its liaison to the national development. Academic teams, each participating economy oversee surveys of demographic representative samples, consisting of two thousands (2000) adults, at least between the ages of 18 and 64 years. 69 economies participated in GEM in 2012.

GEM opined entrepreneurial activity as a continuous process neither an event. As such, the survey on Adult Population (APS) is designed to measure individual participation across a range of phases making up this activity: entrepreneurial intention, potential entrepreneurship, nascent and new entrepreneurship activity, established business ownership [4].

\section{Findings}

Positive attitudes about entrepreneurship in an economy could improve the propensity of people to engage in this activity, which in turn can have a marked influence on the well-being and economic growth of that country. In addition, attitudes can play an important role in the extent to which society may provide both cultural and financial support and to generate potential stakeholders that could enhance and assist the efforts of entrepreneurs.

Opportunities' perceived and intentions in general, most individuals in Sub-Sahara Africa (SSA) have a high perception about the existence of opportunities for starting a new business within next six months, with the exception of South Africa 35\%, it is below the average of $70 \%$ for that region. However, it should be noticed that the forms of businesses in which they currently engage differ from more developed economies.

The perception of that individuals have the real skills to start and run successfully a business are higher (over $76 \%$ ) in every countries, against South Africa (39\%) being the exception.

\subsection{Entrepreneurship, Career Choice for African}

All over the world entrepreneurship is related to employment generation, innovation and economic growth. But over thirty past years, entrepreneurship has been displayed in Africa [5]. And Africa's problem is basically higher youth unemployment. Integrating more youths into the business sector can provide more solutions relied on unemployment. Poverty and underemployments both can be solved. According to Chigunta and his team, entrepreneurship in Africa is not developed. Entrepreneurship may be particularly a small solution to youth unemployment and could be viewed as an innovative strategy that professionally could develop active individuals and increase the potential of young people in that area. Moreover, risk taking boss can be created through targeted 
support and development. The benefits of becoming an entrepreneur include the creation of value, taking risks, making life better and being ambitious.

World Bank showed that the labor force per year in Uganda is increasing 3.4\% (resulting in 390,000 new job seekers) and yet each year only 8120 jobs are created. Many people in Kenya faced unemployment issues (78\%). The higher level of unemployment, and the challenges, this presents for themselves, families and society, have been notified. Whereas efforts have been made to promote entrepreneurship among the Youth, most of them seem urban youth as the target. That is a small proportion of the overall youth population. Previous researches have emphasized the differences between developed and developing countries but have not gone further beyond the differentiation between rural and urban youth entrepreneurs within countries. We focus on the environment of business because there is any business that is done alone, isolated from environment within which it occurs [6].

Entrepreneurship has been associated with the capacity, ability of individuals to create, innovate in business. Some of the literature on entrepreneurship has explained it, based on psychological and cognitive analysis. Another part of the literature has also explained entrepreneurship based on the human capital investment. Lazear did a test on human capital approach by analyzing students. He found that those who follow a broader course selection tend to be more entrepreneurial that those who are specialized [7].

While caution should be exercised, entrepreneurship is not seen as a solution that can cure all society's social ills. It is argued that entrepreneurship has a number of potential advantages and benefits. An obvious, and perhaps significant, benefit of entrepreneurship is that it creates employment for the youth who owns the business. This is especially the case in an economy subject to rationalization, change and restructuring.

The research shows that the average age to start a business is 40 . That is consistent with some previous research, which found the average and median age of technology company founders to be 39 .

- Over $95 \%$ of respondents themselves had earned bachelor's degrees, and $47 \%$ had more advanced degrees.

- Seventy-five percent ranked their academic performance among the top $30 \%$ of their high school class, with a majority $(52 \%)$ ranking their performance among the top $10 \%$.

- Over $71 \%$ of respondents came from middle-class backgrounds. Additionally, nearly $22 \%$ said they came from upper-lower-class families. Less than 1\% came from extremely rich or extremely poor backgrounds.

\subsection{China's Entrepreneurial Engagement in West-Africa}

Over the past two decades in Nigeria, economic and investment interest of many global businesses has been the subject of many academic researches [8]-[10]. Many of those are government-owned entities, non-governmental entities and private entrepreneurs headquartered in China, Great Britain and the United States of America. [11] specified the People Republic of China is currently Nigeria's leading strategic partner, with business investment in many parts of the country. The most attractive reason is the availability of the natural resources, oil, raw materials and cheaper labor force. Previous studies have stressed that Nigeria's economic reforms are mechanism for balancing global competing interests in the country's economic environment [12] [13].

Many researchers have examined the increasing interest of the firms in Africa. There were some authors that expressed different kind of points of view in terms of short or long term objective of foreign businesses in the country [14]-[16]. Whereas, others were consistent toward their positions regarding opportunities of investment [17] [18]. In the West of Africa especially in Nigeria, studies indicate some companies, foreign investors lack of challenges' knowledge and issues associated with the climate of entrepreneurial businesses [19].

A previous research questions whether Chinese aid, trade and corporate social responsibility would help to reduce poverty in the Africa (Nigeria) and drive growth [20] [21]. He argued that in order for sustain growth and development, demonstrable progress has to be achieved in the sectors of policy choices, human capital, entrepreneurship, leadership and culture. In his comparative research, Rotberg expressed that Chinese strong presence in Africa has occurred as a result of mutual benefits in a trade agreement, this is favorable climate for the host countries. China displaced American, European and Japanese in West-Africa through its diplomatic offensive in investments, trades, and aid advances. China became the largest investor, trader, buyer, aid donor, and strategic partner with Africa nations.

\subsection{Development of Entrepreneurship in China}

Entrepreneurship in China took many different forms. There are three main varieties that can be identified. The 
first occurred before reform and through the 80's consisting of very small-scale activities in retail and services such as street vendors, businesses... Perhaps more accurately referred to as a "self-employed" rather than "entrepreneurs", those involved were social status, often criminals and illegal migrants, and low education. They started out on their own because they were excluded from the state system. Some achieved success beyond their expectations. But for most business was means of subsistence. The second group emerged in the late of 1980's, with more highly educated individuals, often engineers or SOE managers, operating on a larger scale out of choice rather than a necessity. These businesses, known as saying "qiye", operated in all sectors, ranging from restaurant to transportation to manufacturing, especially the production of inputs for SOE's. The third type is the foreign educated or train Chinese returning to china to start business. This type of entrepreneurship has been evident recently in the flourishing internet sector. Each of these types of entrepreneurs operates in somewhat different environment, under different constraints and has distinctive characteristics. We focus primarily on the second type, which we believe is the most interesting group. After all for those who have no other choice, starting a business carries no risk, while others the risk can be tremendous.

But the emergence of China's entrepreneurs has not been without obstacles. By guaranteeing employment and providing social security in the absence of a national safety net, the lifetime employment system in the stateowned enterprises strongly discouraged urban workers from becoming self-employed. In the mid-1990s arrived the restructuring of the state-owned enterprises decision appeared, then, private Chinese firms begin to flourish. By providing an alternative source of revenues, the emerging non-states sector has given the government leeway in its efforts to downsize and reform state-owned enterprises.

Another institutional challenge faced by entrepreneurs has been limited assess to credit. A recent estimation by the first Chinese Chief economic of the World Bank suggests that out of 40 million small and medium-sized enterprises in China 2006, less than half of 1\% could obtain loans from banks.

As obstacles, Chinese entrepreneurs have also faced a shortage of key assets such as land or property and unsecure the property rights in a system that did not protect private ownership officially until 2004 (state-owned and privatization of land and buildings has only begun recently.).

Confronted with a China that had historical produced many important inventions, and yet had lagged behind the West economically, Weber attributed the difference to Confucianism. That is a social behavior system condemns pure profit seeking as well as advocates group orientation, conformity, and respect authority. After the success of East Asian countries, Chinese entrepreneurs, opinion focused on the Confucian Values of persistence, diligence, thrift, and strong role played by the family as key supporting factors for entrepreneurial development. In his seminal research into the role culture, Hofstede added fifth cultural dimension, Confucian dynamism; to take into account Fast Asian growth. Kirby and Fan compared a list of sixty traditional Chinese cultural Values constructed from research surveys and a list of entrepreneurial attributes as identified by various authors to determine whether Chinese culture is conductive to the entrepreneurship. They found considerable overlap between the two sets of values, including perseverance, diligence, resource fullness, emotional stability, integrity, intelligence and harmony. But some entrepreneurial attributes response positively (to change, initiative, profit orientation...) in conflict with Chinese values. Conclusion, Chinese values will appear to be partially conducted to entrepreneurship, while some strong barriers may exist. Such conclusion leads to low social status of entrepreneurs China. The role of traditional culture is also influenced by other factors that are political ideology, the degree of openness to foreign values, further. David conducted a more analytic study comparing traits of Chinese managers of SOEs, Chinese entrepreneurs, and US entrepreneurs. Based on survey responses taken from managers in province, he compared the groups along Hofstede's dimension [22].

Overall a sharp contrast existed between Chinese entrepreneurs and Chinese managers regarding individualism, risk and openness to change. Interestingly, the Chinese entrepreneurs score higher than American counterparts on some dimensions, particularly risk tolerance. That is the environmental barriers to entrepreneurship in China which entrepreneurs must overcome. To conclude, Holt said that the similarity between Chinese and US entrepreneurs, and the difference between Chinese entrepreneurs and managers, provides strong evidence for the convergence of entrepreneurial values. Entrepreneurs are flourishing despite the dominant culture, and the additional barriers which culture erects means entrepreneurs who emerge must possess especially strong countervailing individual attributes [23].

According to a previous study about the topics "international entrepreneurship in China" and "the extent and impact of international new ventures in emerging economics", both topics have been neglected [24] [25]. In china the world's largest emerging economy, the size and economy growth performance of the country have generated a large literature in the development and international economic literature on the country's perfor- 
mance [26]. This literature neglected the role of (international) entrepreneurship in China's growth [27]. As Yeung expressed, we need to get more knowledge about the nature and extend of Chinese entrepreneurship across borders [28].

The environment (earth's ecosystem, climate change: "Ecosystem services are the benefits human derive, directly or indirectly, from ecosystem's functions") has impacted the human activities. Industries have a specific role in the reduction of the negative impact [29]. Even more importantly, industry has the potential to reverse negative environmental trends by leading the world into the next industrial revolution [30]-[32]. Today there is a consensus that is growing among the scientific community that climate is, if not caused, then certainly developed [33].

\section{Methodology}

The survey method is to be able to come up with the descriptions for the variables that are of interest and related to the topic. There are parts of collecting publications on the area of study. After comparing West-African development to the Chinese one (using unemployment, healthcare; electricity consumption and GDP), we provide interviews to the employers from the majors cities of Benin (Cotonou; Porto-Novo; Parakou; Bohicon; Abomey...) to collect more data from samples. It focuses on the entrepreneurial activities and two hundreds (200) surveyed people were expected but randomly hundred and eighteen (118) entrepreneurs were targeted (WestAfrica). They described their areas of business, their level of study, their age of entering entrepreneurial activities, etc...

\section{Quantitative Approach on the Enterprise's Exercises}

\subsection{China versus West-Africa}

CIA world organization's research has compared China to African countries (Table 1) [34].

Many factors were found that disable the African development-Unemployment; less investment in healthcare; low consumption of electricity; low GDP capita....

According to CIA, most of the West-African countries have their unemployment rate higher (e.g. Liberia $85 \%$; Senegal $48 \%$; Nigeria 23\%; but Ghana has improved much better $11 \%$ ) whereas China's rate is the lower (4\%) despite the Chinese demographic effects (Figure 1).

World Health Organization found that African countries invest little fund in healthcare, whereas China significantly does. The higher amount is a proof (Table 1).
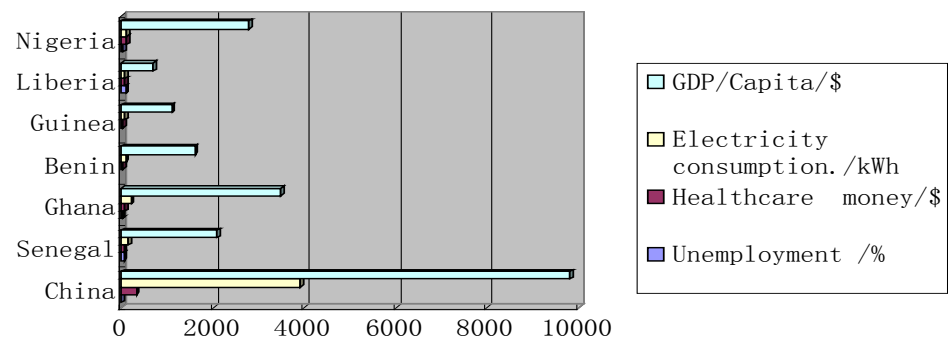

Figure 1. Comparison between China and West-Africa. Source: CIA World Factbook; World Health Organization.

Table 1. China versus West-Africa.

\begin{tabular}{|c|c|c|c|c|}
\hline & Unemployment rate & Healthcare money & Electricity consumption & GDP/Capita \\
\hline China & 4.1 & 321.7 & 3,25 & 9800 \\
\hline Senegal & 48 & 51.2 & 162 & 2100 \\
\hline Ghana & 11 & 83 & 206 & 3500 \\
\hline Benin & & 33.1 & 85 & 1600 \\
\hline Guinea & & 32 & 78 & 1100 \\
\hline Liberia & 85 & 65.5 & 76 & 700 \\
\hline Nigeria & 23.9 & 94.3 & 115 & 2800 \\
\hline
\end{tabular}

Source: CIA World Factbook; World Health Organization. 
The lower consumption of electricity in West-Africa explains the scarcity of the industries in the countries. China's consumption surpasses too largely African countries, and that results from the industrialization of that country. After the new reform policy of Deng Xiao Ping in 1978, China got open to the World and foreign investment increased rapidly and boosted the country's economy. Then, Chinese GDP has more significantly improved than other developing countries.

We believe that those four (4) values (GDP per capita; unemployment rate; healthcare money; electricity consumption) measure the level of development. But we would like to rely on the main issues for the youth's daily matters (unemployment) that are common to other African nation people. lic...

The main ways to create more job opportunities is to go through the partnerships private-public; public-pub-

\subsection{Frame Work: Entrepreneurial Activities in Benin}

Nowadays people with less of experiences, diplomas, less level of education can create also their own enterprises as well as those with higher education. The following entrepreneurial activities are noticed in the West-Africa especially in Benin Cotonou to understand and know which forms of employers exist in Benin Society, what are their characteristics, their influences in order to stimulate more innovations in that specific sector. The market research shows that there exist teaching \& liberal profession, restoration, sewing (cloth-maker), transport \& tourism; hairdressing (hair-maker); trade; communication \& insurance; services.

According to this research, the environment shows eight types of entrepreneurial activities that are Trade $38.9 \%$; services $21.18 \%$; hair-maker $16.94 \%$; communication and insurance $6.78 \%$, restauration $5.93 \%$, clothmaker $4.23 \%$ and transport tourism; teaching liberal that represent the lower activities respectively only with $3.38 \%$ and $2.54 \%$ (Table 2; Figure 2).

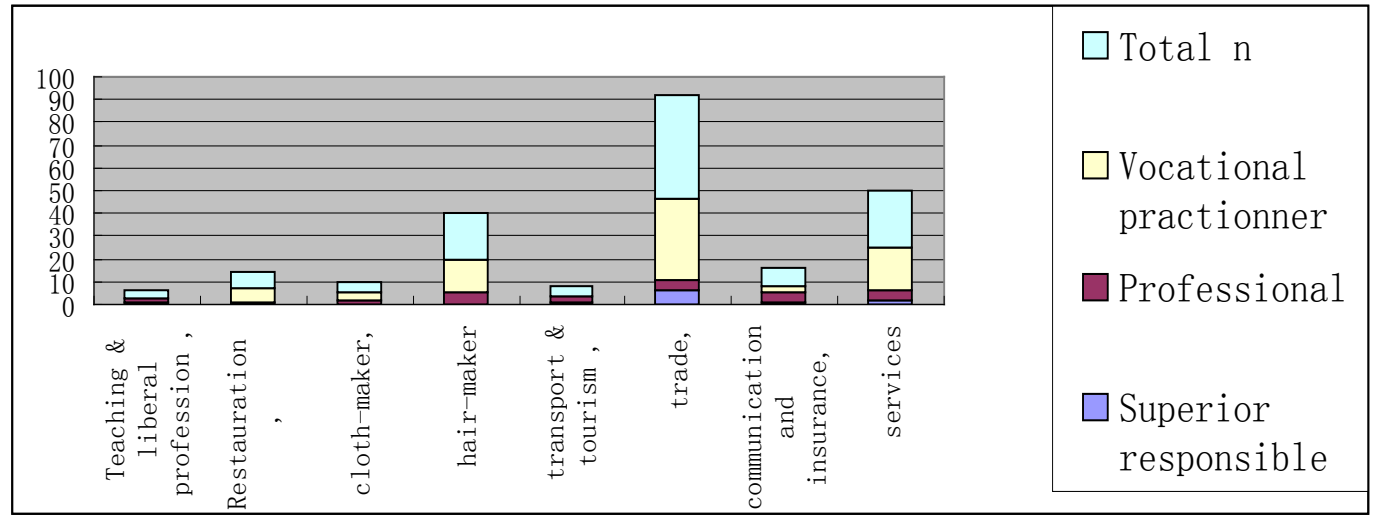

Figure 2. Entrepreneurial activities in Benin.

Table 2. Entrepreneurial sectors in Benin.

\begin{tabular}{|c|c|c|c|c|}
\hline Profile & Executive Senior & Professional & Vocational practitioner & Total n \\
\hline Teaching \& liberal profession & 1 & 2 & 0 & 3 \\
\hline Restoration & 0 & 1 & 6 & 7 \\
\hline Sewing & 0 & 2 & 3 & 5 \\
\hline Hairdressing & 0 & 5 & 15 & 20 \\
\hline Transport \& tourism & 1 & 3 & 0 & 4 \\
\hline Trade & 6 & 5 & 35 & 46 \\
\hline Communication and insurance & 1 & 4 & 3 & 8 \\
\hline Services & 2 & 4 & 19 & 25 \\
\hline Total $\mathrm{n}$ & 11 & 25 & 82 & 118 \\
\hline$\%$ & 9.32 & 21.18 & 69.49 & 100 \\
\hline
\end{tabular}


It is noticed that the sectors of trade, services and hair-maker attract more people to invest and create their own enterprises. The other sectors of communication and insurance, restauration, cloth-maker... are less interested and may due to a particular or technical knowledge.

To make a difference among the entrepreneurs, we refer to their higher professional degree (Table 3 \& Figure 3). $70 \%$ of entrepreneurs are vocational practitioners whereas $30 \%$ represent the degrees holders. Among those $21.32 \%$ provides the high school level whereas the rest the second university level provides 9.32 (baccalaureate; technical \& professional certificate; or professional and technical aptitude certificate).

The non-holders degree, vocational practitioners surveyed, according to their conditions are attracted by the small details businesses such as sale of clothes; office features; building materials. Almost $82.92 \%$ among the 82 have completed successfully primary school.

\section{Classification on the age of entrepreneurs}

$5.93 \%$ represents the percentage of the young entrepreneurs that are under 25 years old. The deduction is that people create their enterprises before reaching the age of 25 . The number of entrepreneurs starts increasing significantly the following years till to the 31 to 40 years old. The entrepreneurial activities receive a decline after 40 years old. Between 41 to 50 years old it is $15.25 \%$ whereas from 50 and above it is $12.71 \%$. Another way, after reaching 40 years old your entrepreneurial exercises become weaker and affect the process (Table $4 \&$ Figure 4).

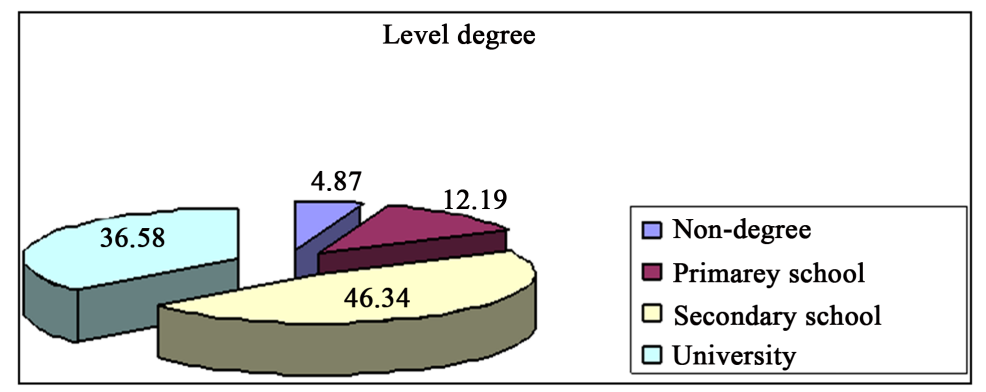

Figure 3. Entrepreneurs level of study.

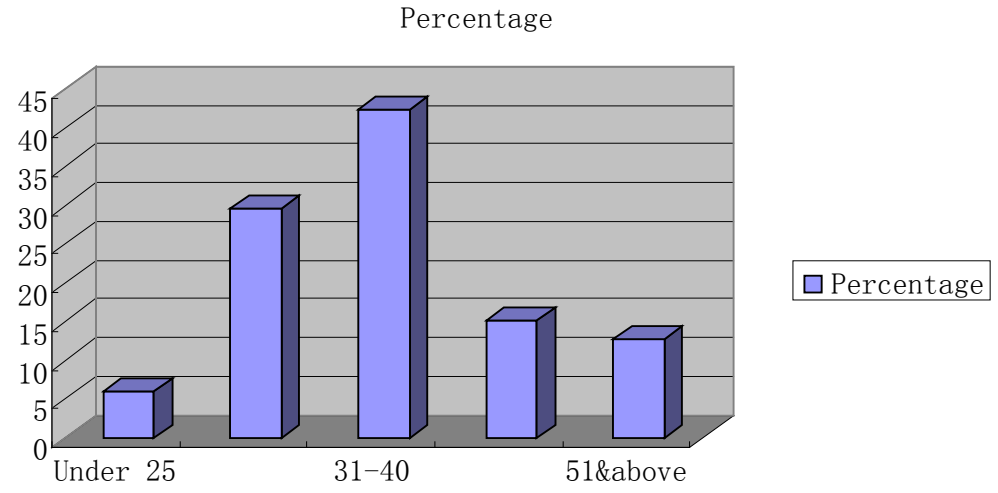

Figure 4. Age classification in entrepreneurial sector in Benin.

Table 3. Degree level.

\begin{tabular}{ccc}
\hline Level of study & Quantity n & Percentage \\
\hline Non-degree & 4 & 4.87 \\
Primary school & 10 & 12.19 \\
Secondary school & 38 & 46.34 \\
University & 30 & 36.58 \\
Total & 82 & 100 \\
\hline
\end{tabular}


Table 4. Entrepreneur's age classification.

\begin{tabular}{ccc}
\hline Age & Quantity & Percentage \\
\hline Under 25 & 7 & 5.93 \\
$25-30$ & 35 & 29.66 \\
$31-40$ & 50 & 42.37 \\
$41-50$ & 18 & 15.25 \\
$51 \&$ above & 8 & 12.71 \\
Total & 118 & 100 \\
\hline
\end{tabular}

The age categorization of African youth entrepreneurs suggests that youth-run enterprises can be placed at different points on the enterprise continuum. Conceptually, pre-entrepreneurs and budding entrepreneurs can be viewed as an entry point into informal and micro-enterprises. On the other hand, emergent entrepreneurs can be seen as running micro and small enterprises.

\subsection{Comment}

Successful entrepreneurship requires a stronger enabling environment and political leadership. While individuals with the right skills, energy and ambition are the basis for entrepreneurship, it will only flourish with appropriate economic policies, relevant institutions and infrastructure.

The age categorization of African youth entrepreneurs suggests that youth-run enterprises can be placed at different points on the enterprise continuum. Conceptually, pre-entrepreneurs and budding entrepreneurs can be viewed as an entry point into informal and micro-enterprises. On the other hand, emergent entrepreneurs can be seen as running micro and small enterprises.

\section{Limitations on the Study}

With this study we hope to contribute to the knowledge base and help to satisfy people. No matter they are in quest of advises or theories that can solve their problem, we would hopefully have an approach of solutions toward the topic in order to reinforce and remote the faith, the confidence, provide useful information and methods for the society and in the business scope as well. But there exist a limitation in this study. Mainly constraints may be the financial and distance because in Africa (Guinea, Togo; Ghana...) as well, we often base on the internet and others tools of communications like phone, post office...

Major limitation may derive from the use sampling in selecting the important personality of the companies that are sometimes unavailable. Anyway an effort is done to conduct this research using the resources available.

\section{References}

[1] Mckeown, M. (2008) The Truth about Innovation.

[2] Peter, F.D. (1985) Innovation and Entrepreneurship Practice \& Principle.

[3] Oviatt, B.M. and Mc Dougall, P. (2005) Defining International Entrepreneurship and Modeling the Speed of Internationalization. Entrepreneurship Theory and Practice, 29, 537-554. http://dx.doi.org/10.1111/j.1540-6520.2005.00097.x

[4] Chigunta, F., Schnurr, J., Wilson, D.J. and Torres, V. (2005) Being "Real" about Youth Entrepreneurship in Eastern and Southern Africa Implications for Adults. Institutions and Sector Structures Working 72.

[5] Marsden, K. (1992) African Entrepreneurs Pioneers of Development. Small Enterprise development, 3, 15-25.

[6] Fry, F.L., Stoner, C.R. and Hattwick, R.E. (2003) Business: An Integrative Approach. Business: An Integrative Approach with Student CD and PowerWeb

[7] Lazear, E.P. (2003) Teacher Incentives. Swedish Economic Policy Review, 10, 179-214.

[8] Broadman, D. (2007) Africa's Silk Road. The World Bank, Washington DC.

[9] Nwoye, M. (2010) Entrepreneurship Development and Investment Opportunities in Nigeria. Highcliff Publisher Inc., Lagos. 
[10] Laorossi, M. and Radwan, I. (2009) An Assessment of the Investment Climate in Nigeria. The World Bank, Washington DC.

[11] Taylor, I. (2009) China's New Role in Africa. Lynne Rienner Publishers, Bouler.

[12] OkonjoIweala, N. and Kwaako, O. (2007) Nigeria's Economic Reform: Progress and Challenges. Brookings Institution, Washington DC.

[13] Tull, D.M. (2006) China's Engagement in Africa: Scope, Significance and Consequences. Journal of Modern African Studies, 44, 459-479. http://dx.doi.org/10.1017/s0022278x06001856

[14] Bloom, N. and Van Reene, J. (2006) Measuring and Explaining Management Practices across Firms and Countries. Center for Economic and Performance (CEP) Discussion Paper Number: 716.

[15] Escribano, A. and Guasch, J. (2005) Assessing the Impact of Investment Climate on Productivity Using Firm Level Data Methodology and the Cases of Guatemala, Honduras, and Nicaragua. Discussion Paper WPS 3621, The World Bank, Washington DC. http://dx.doi.org/10.1596/1813-9450-3621

[16] UNCTAD (United Nations Conference on Trade and Development) (2005) Economic Development in Africa: Rethinking the Role of Foreign Direct Investment. Geneva, United Nations.

[17] World Bank (2006) World Development Indicators. The World Bank, Washington DC.

[18] Van Wijnbergen, S. (2002) An Assessment of the Private Sector in Nigeria: A Pilot Investment Climate Assessment. The World Bank, Washington, DC.

[19] Oyewole, P. and Okoro, E. (2008) Who Pays More in International Market? An Examination of Terms of Trading and Tariff of the Countries of Africa. Innovative Marketing, 4, 6-11.

[20] Utomi, P. (1998) Managing Uncertainty: Competition and Strategy in Emerging Economies. Spectrum Books, Ibadan.

[21] Rotberg, R.I. (2008) China into Africa: Trade, Aid, and Influence. The Brookings Institution, Washington DC.

[22] David, K. and Fan, Y. (1995) Chinese Cultural Values and Entrepreneurship: A Preliminary Consideration. Journal of Enterprising Culture, 3, 245-260. http://dx.doi.org/10.1142/S0218495895000131

[23] Holt, D.H. (1997) A Comparative Study of Values among Chinese and US Entrepreneurs: Pragmatic Convergence between Contrasting Cultures. Journal of Business Venturing, 12, 483-505. http://dx.doi.org/10.1016/S0883-9026(96)00131-0

[24] Yamakawa, Y., Peng, M.W. and Deeds, D.L. (2008) What Drives New Ventures to Internationalize from Emerging to Developed Economies? Entrepreneurship Theory and Practice, 32, 59-82. http://dx.doi.org/10.1111/j.1540-6520.2007.00216.x

[25] Naude, W.A. (2008) Entrepreneurship in Economic Development. WIDER Research Paper RP 2008/20, United Nations University, Helsinki.

[26] Adam, F.G., Gangnes, B. and Shachmurove, Y. (2006) Why Is China So Competitive? Measuring and Explaining China's Competitiveness. The World Economy, 29, 95-122. http://dx.doi.org/10.1111/j.1467-9701.2006.00773.x

[27] Alon, I. and Lerner, M. (2008) International Entrepreneurship in China: Lesson from Global Entrepreneurship Monitor. The Next Globalization Conference on Transnational Entrepreneurship, Waterloo, 30 April 2008. www.wlu.ca/documents/30218/International Entrepreneurship.pdf

[28] Yeung, H.W.C. (2004) International Entrepreneurship and Chinese Business Research. In: Dana, L.P., Ed., Handbook of Research on International Entrepreneurship, Edward Elgar, Cheltenham, 73-93. http://dx.doi.org/10.4337/9781845420512.00013

[29] Costanza, R., d’Arge, R., de Groot, R., Farber, S., Grasso, M., Hamson, B., Limburg, K., Naeem. S., O’Neil, R.V., Paruelo, J., Raskin, R.G., Sutton, P. and van den Belt, M. (1997) The Value of World's Ecosystem Services and Natural Capital. Nature, 387, 253-260. http://dx.doi.org/10.1038/387253a0

[30] Hawken, P., Lovings, A. and Lovins, L.H. (1999) Natural Capitalism: Creating the Next Industrial Revolution. Little Brown and Company, New York.

[31] Senge, P. and Carstedt, G. (2001) Innovating, Our Way to the Next Industrial Revolution. MIT Sloan Management Review, 42, 24-38.

[32] Braungart, W. and McDonough, M. (2002) Cradle to Cradle: Remaking the Way We Make Things. North Point Press, Straus and Giroux19 Union Scare West New York 10003.

[33] Bolin, B. (1997) Scientific Assessment of Climate Change. In: Fermann, G., Ed., International Politics of Climate Change, Scandinavian University Press, Olso, 83-109.

[34] World Health Organization (2013) CIA World Factbook. 


\section{Submit or recommend next manuscript to SCIRP and we will provide best service for you:}

Accepting pre-submission inquiries through Email, Facebook, LinkedIn, Twitter, etc.

A wide selection of journals (inclusive of 9 subjects, more than 200 journals)

Providing 24-hour high-quality service

User-friendly online submission system

Fair and swift peer-review system

Efficient typesetting and proofreading procedure

Display of the result of downloads and visits, as well as the number of cited articles

Maximum dissemination of your research work

Submit your manuscript at: http://papersubmission.scirp.org/ 